\title{
Diagnostic and Clinical Factors Associated with Pulpal and Periapical Pain
}

\author{
Carlos ESTRELA ${ }^{1}$ \\ Orlando Aguirre GUEDES ${ }^{1}$ \\ Júlio Almeida SILVA ${ }^{1}$ \\ Cláudio Rodrigues LELES ${ }^{1}$ \\ Cyntia Rodrigues de Araújo ESTRELA ${ }^{1}$ \\ Jesus Djalma PÉCORA² \\ ${ }^{1}$ Dental School, UFG - Federal University of Goiás, Goiânia, GO, Brazil \\ ${ }^{2}$ Ribeirão Preto Dental School, USP - University of São Paulo, Ribeirão Preto, SP, Brazil
}

\begin{abstract}
A retrospective survey was designed to identify diagnostic subgroups and clinical factors associated with odontogenic pain and discomfort in dental urgency patients. A consecutive sample of 1,765 patients seeking treatment for dental pain at the Urgency Service of the Dental School of the Federal University of Goiás, Brazil, was selected. Inclusion criteria were pulpal or periapical pain that occurred before dental treatment (minimum 6 months after the last dental appointment), and the exclusion criteria were teeth with odontogenic developmental anomalies and missing information or incomplete records. Clinical and radiographic examinations were performed to assess clinical presentation of pain complaints including origin, duration, frequency and location of pain, palpation, percussion and vitality tests, radiographic features, endodontic diagnosis and characteristics of teeth. Chi-square test and multiple logistic regression were used to analyze association between pulpal and periapical pain and independent variables. The most frequent endodontic diagnosis of pulpal pain were symptomatic pulpitis $(28.3 \%)$ and hyperreactive pulpalgia $(14.4 \%)$, and the most frequent periapical pain was symptomatic apical periodontitis of infectious origin (26.4\%). Regression analysis revealed that closed pulp chamber and caries were highly associated with pulpal pain and, conversely, open pulp chamber was associated with periapical pain $(\mathrm{p}<0.001)$. Endodontic diagnosis and local factors associated with pulpal and periapical pain suggest that the important clinical factor of pulpal pain was closed pulp chamber and caries, and of periapical pain was open pulp chamber.
\end{abstract}

Key Words: urgency, dental pain, pulpal pain, periapical pain, apical periodontitis.

\section{INTRODUCTION}

Pulpal and periapical pains are two of the reasons why patients seek dental care. Pain experienced before, during or after endodontic therapy is a serious concern to both patients and endodontists (1). Although pain receives substantial attention from all healthcare providers, many patients consider pain and dentistry to be synonymous (2). Pain is a complex phenomenon, and dental pain, a multifactorial or multidimensional experience, involves sensory responses and emotional, conceptual, and motivational aspects (3). Moreover, the pain threshold of intradental nerves may be affected by inflammation, detected by receptors expressed on pulpal nociceptors (2), or local changes in intrapulpal pressure (4).

In the United States, about $22 \%$ of adults aged 18 years or older are estimated to have experienced at least one type of orofacial pain, namely pain in the jaw joints, in front of the ear, face or cheeks, burning sensation in the mouth or tongue, toothache, and oral sores (5).

The perception of pain is a devastating experience, and its variable levels of discomfort are a challenge to diagnostic methods, endodontic therapy and endodontic knowledge $(6,7)$. Human pain is difficult to measure because it is a sensorial and personal experience modified by several factors (8). Clinical symptoms do not permit the evaluation of the extension of pulpal and periapical injuries (7) and neither associate it with the microscopic characteristics $(1,2,6,7,9-12)$. The evaluation of pain perception by qualitative and quantitative methods has been carefully discussed $(2,8)$. Whilst some studies have investigated the incidence of pain and its correlation with 
clinical factors during and after root canal treatment $(13,14)$, others have determined the association of periapical and pulpal symptoms with bacteria, enzymes and toxins (15-18). Few epidemiological studies have focused on urgencies that occur before the beginning of endodontic treatment (7).

Knowledge of the frequency and clinical factors associated with pulpal and periapical pain may provide important information to the planning of preventive or therapeutic strategies, as well as to the understanding of the outcomes of urgent endodontic treatment. Thus, this study aimed to determine the frequency and clinical factors associated with pulpal and periapical pain experienced before dental treatment.

\section{MATERIAL AND METHODS}

A retrospective survey evaluated patients who sought treatment at the Dental Urgency Service of the Dental School of the Federal University of Goiás, Brazil, in 2005 and 2006 due to odontogenic discomfort or pain associated with inflammation, infection, or both. After approval by the University Ethics Committee (Protocol number 055/2005), a consecutive sample of 1,765 patients (675 males) of low socioeconomic status with mean age of 32 years and history of severe odontogenic pain or swelling, was formed. Inclusion criterion was pulpal or periapical diseases that occurred before dental treatment (minimum of 6 months after the last dental appointment), and the exclusion criteria were teeth with odontogenic developmental anomalies and missing information or incomplete records. Data were collected by two professors of the institution, who discussed the diagnostic criteria. When a consensus was not reached, a third professor made the final decision.

The analysis of pulpal and periapical pain followed guidelines for the clinical diagnosis of pulpal and periapical diseases: hyperreactive pulpalgia, symptomatic pulpitis, symptomatic apical periodontitis of traumatic or infectious origin, periapical abscess without sinus tract, periapical abscess with sinus tract (7). During the clinical examination, data about medical and dental history were collected together with the following clinical characteristics of the pain: type (provoked, spontaneous), duration (short, long), frequency (continuous, intermittent) and site (local, diffuse). The clinical examination included the evaluation of all visual biophysical characteristics of the tooth and surrounding tissues, palpation, percussion and pulpal vitality tests, and radiographic studies. Dental urgencies associated with other odontogenic problems, such as traumatic dental injuries, periodontal pain, temporomandibular joint (TMJ) pain, and postoperative pain, were classified into the "other" category.

Frequency was determined according to clinical classifications of pulp and periapical diseases described previously (7). The characteristics analyzed to determine clinical factors were: (a) for pulpal pain: gender, position of tooth (anterior, posterior), arch (maxilla, mandible), intact crown (no, yes), open pulp chamber (no, yes), caries (no, yes), amalgam restoration (no, yes), resin restoration (no, yes), temporary restoration (no, yes), fractured crown (no, yes); (b) for periapical pain: gender, position of tooth (anterior, posterior), arch (maxilla, mandible), endodontic treatment (no, yes), intact crown (no, yes), open pulp chamber (no, yes), caries (no, yes), amalgam restoration (no, yes), resin restoration (no, yes), temporary restoration (no, yes), fractured crown (no, yes); restoration with post (no, yes).

Frequency of pulpal and periapical pain was calculated based on the clinical classification of inflamed pulpal and periapical tissues. Chi-square test assessed the clinical factors associated with pulpal and periapical pain, and multiple logistic regression tested the association of pulpal and periapical pain with independent clinical factors. Data were analyzed using the SPSS for Windows 15.0 statistical software (SPSS Inc., Chicago, IL, USA).
Table 1. Frequency of pulpal and periapical pain $(n=1,765)$.

\begin{tabular}{lr}
\hline Types of urgencies & $\mathrm{n}(\%)$ \\
\hline Pulpal origin & $499(28.3)$ \\
Symptomatic pulpitis & $255(14.4)$ \\
Hyperreactive pulpalgia & \\
Periapical origin & $466(26.4)$ \\
Symptomatic apical periodontitis of infectious origin & $164(9.30)$ \\
Periapical abscess without sinus tract & $68(3.90)$ \\
Periapical abscess with sinus tract & $11(0.60)$ \\
Symptomatic apical periodontitis of traumatic origin & $302(17.1)$ \\
Other & $1,765(100.0)$ \\
\hline
\end{tabular}




\section{RESULTS}

Of the studied teeth, 889 were mandibular and
876 were maxillary, including. They were permanent molars $(n=974)$, premolars $(n=399)$, permanent canines $(n=95)$, permanent incisors $(n=203)$ and primary teeth $(n=94) ; 93$ had root canal treatment, and 1,672 did not. Of all odontogenic urgencies, the highest frequency rates were $28.3 \%$ for symptomatic pulpitis and $26.4 \%$ for apical periodontitis of infectious origin. The lowest frequency rate was $0.6 \%$ for symptomatic apical periodontitis of traumatic origin (Table 1). Clinical factors of odontogenic pain are shown in Tables 2 and 3. Logistic regression analysis revealed that the most important clinical factors for pulpal pain were closed pulp chamber $(\mathrm{OR}=114.08$, $\mathrm{CI}=36.29-358.66)$ and caries $(\mathrm{OR}=3.51$, $\mathrm{CI}=2.72-4.53$ ) and, for periapical pain, open pulp chamber $(\mathrm{OR}=7.34, \mathrm{CI}=5.52$ 9.75) (Table 4).

\section{DISCUSSION}

The distribution, prevalence, frequency and severity of diseases, especially when associated with pain, can be favored by epidemiological data (20,21). Planning preventive or therapeutic strategies and evaluating outcomes, depend on these data $(22,23)$.

Data for this retrospective survey were carefully collected by professors who work at the Dental Urgency Service of the Federal University of Goiás, Brazil and are prepared to use the same clinical diagnosis guidelines (7). Although different classification systems for pulpal and periapical diseases are found in the literature $(1,2,6,7,9,11,24)$, there seems to be evidence to support the consensus about the absence of correlation between clinical events, radiographic assessment and histopathological characteristics $(1,2,9,10,12,19)$. Therefore, a clinical classification of pulpal and periapical disease, which the authors were familiar with, was used in our study (7).

Previous studies $(13,14)$ have found an association of several factors 
Table 3. Clinical factors associated with periapical pain $(n=1765)$.

\begin{tabular}{|c|c|c|c|c|c|}
\hline \multirow{2}{*}{$\begin{array}{l}\text { Clinical } \\
\text { factor }\end{array}$} & \multirow[b]{2}{*}{$\mathrm{n}(\%)$} & \multicolumn{2}{|c|}{ Periapical pain } & \multirow[b]{2}{*}{$c^{2}$} & \multirow[b]{2}{*}{$\mathrm{p}$} \\
\hline & & $\begin{array}{c}\text { Yes } \\
(n=774)\end{array}$ & $\begin{array}{c}\text { No } \\
(n=991)\end{array}$ & & \\
\hline \multicolumn{6}{|l|}{ Gender } \\
\hline Male & $675(38.2)$ & 209 & 466 & 0.440 & 0.507 \\
\hline Female & $1090(61.8)$ & 354 & 736 & & \\
\hline \multicolumn{6}{|c|}{ Position of tooth } \\
\hline Anterior & $303(17.2)$ & 110 & 193 & 3.268 & 0.071 \\
\hline Posterior & $1462(82.8)$ & 453 & 1009 & & \\
\hline \multicolumn{6}{|l|}{ Arch } \\
\hline Maxilla & $876(49.6)$ & 304 & 572 & 6.300 & 0.012 \\
\hline Mandible & $889(50.4)$ & 259 & 630 & & \\
\hline \multicolumn{6}{|c|}{ Endodontic treatment } \\
\hline Yes & $93(5.3)$ & 56 & 37 & 36.238 & $<0.001$ \\
\hline No & $1672(94.7)$ & 507 & 1165 & & \\
\hline \multicolumn{6}{|l|}{ Intact crown } \\
\hline Yes & $102(5.8)$ & 11 & 91 & 22.216 & $<0.001$ \\
\hline No & $1663(94.2)$ & 552 & 1111 & & \\
\hline \multicolumn{6}{|c|}{ Open pulp chamber } \\
\hline No & $1477(83.7)$ & 364 & 1113 & 2.192 & $<0.001$ \\
\hline Yes & $288(16.3)$ & 199 & 89 & & \\
\hline \multicolumn{6}{|l|}{ Caries } \\
\hline No & $473(26.8)$ & 124 & 349 & 9.605 & 0.002 \\
\hline Yes & $1292(73.2)$ & 439 & 853 & & \\
\hline \multicolumn{6}{|c|}{ Amalgam restoration } \\
\hline No & $1391(78.8)$ & 489 & 902 & 32.047 & $<0.001$ \\
\hline Yes & $374(21.2)$ & 74 & 300 & & \\
\hline \multicolumn{6}{|c|}{ Resin restoration } \\
\hline No & $1663(94.2)$ & 523 & 1140 & 2.669 & 0.102 \\
\hline Yes & $102(5.8)$ & 40 & 62 & & \\
\hline \multicolumn{6}{|c|}{ Temporary restoration } \\
\hline No & 1657 (93.9) & 520 & 1137 & 3.319 & 0.068 \\
\hline Yes & $108(6.1)$ & 43 & 65 & & \\
\hline \multicolumn{6}{|c|}{ Fractured crown } \\
\hline No & $1720(97.5)$ & 540 & 1180 & 7.847 & 0.005 \\
\hline Yes & $45(2.5)$ & 23 & 22 & & \\
\hline \multicolumn{6}{|c|}{ Restoration with post } \\
\hline No & $1753(99.3)$ & 558 & 1195 & 0.531 & 0.466 \\
\hline Yes & $12(0.7)$ & 5 & 7 & & \\
\hline
\end{tabular}

with incidence of postoperative pain during and after endodontic therapy, such as gender, age, tooth position, intracanal irrigants, intracanal dressings, root canal fillings, number of appointments, and apical periodontitis. Oguntebi et al. (14) studied postoperative pain in association with the type of emergency treatment of symptomatic pulpitis, and found that the type of endodontic emergency procedure was a significant predictor of severe postoperative pain.

The combination of various factors of the same clinical situation may interfere in research outcomes. Therefore, clinical criteria should be carefully standardized. Based on inclusion criteria, this study only determined pulpal and periapical pain that developed before dental treatment. The higher frequency of odontogenic pain indicated the occurrence of symptomatic pulpitis and apical periodontitis of infectious origin. These common symptomatic diseases are caused by microorganisms, as previously described (15-20). Khabbaz et al. (18) determined the presence or absence of endotoxins in the superficial and deep layers of carious lesions of symptomatic and asymptomatic teeth with vital pulps, measured the amount of endotoxin, and associated the presence of endotoxins with the acute pulpal pain caused by irreversible pulpitis. Greater amounts of endotoxin were found in caries of painful teeth compared with teeth without symptoms. Hahn and Liewehr (17) discussed the association between caries bacteria, host responses, and clinical signs and symptoms of pulpitis, and reported that caries bacteria and inflammatory responses (proinflammatory and antiinflammatory cytokines) in the dental pulp are important aspects to understand pulpitis pathogenesis. Recent advances in immunology and neurophysiology explain some clinical signs of pulpitis, such as the proinflammatory properties 
of lipoteichoic acid, which is a common virulence factor of Gram-positive bacteria found among caries bacteria. Sundqvist et al. (16) evaluated the ability of bacteria of pulpal necrosis to induce purulent infections, and found that certain acute exacerbations are caused by polymicrobial infections in which important microorganisms achieve pathogenicity by synergism.

In the present study, one important clinical factor for pulpal pain was caries. This result is in agreement with those reported in other studies that correlated caries with symptomatic pulpitis $(17,18)$. The significant clinical factor for periapical pain was open pulp chamber, which may be explained because of the continuous root canal contamination that promotes polymicrobial infection, increases the number of microorganisms $(15,16)$, and favors bacterial synergism (16). Horiba et al.(15) showed that teeth with clinical symptoms have great amounts of endotoxin. The endotoxin detection rates and the mean endotoxin content were higher for teeth with exudations than for teeth with dry root canals. Jacinto et al. (19) also found high endotoxin concentrations in root canals of symptomatic teeth. There was a positive correlation between endotoxin concentration in root canals and the presence of endodontic signs and symptoms.

The type of restoration most often associated with pulpal pain was amalgam, while temporary and resin restorations were most frequently associated with periapical pain. Fracture of amalgam restorations with microbial leakage or not, may cause pulpal pain. Resin restorations were a clinical factor for periapical pain. This type of restoration without adequate pulp protection,

Table 4. Logistic regression analysis for each explanatory variable for pulpal and periapical pain in odontogenic urgencies $(n=1765)$.

\begin{tabular}{lcc}
\hline \multirow{2}{*}{$\begin{array}{l}\text { Explanatory } \\
\text { variable }\end{array}$} & \multicolumn{2}{c}{ Logistic regression analysis } \\
\cline { 2 - 3 } & OR $(95 \% \mathrm{CI})$ & $\mathrm{p}$ value \\
\hline Pulpal pain & & \\
Closed pulp chamber & $114.08(36.29-358.66)$ & $<0.001$ \\
Caries & $3.51(2.72-4.53)$ & $<0.001$ \\
Amalgam restoration & $2.06(2.72-4.53)$ & $<0.001$ \\
Posterior teeth & $1.75(1.25-2.43)$ & 0.001 \\
Periapical pain & & \\
Open pulp chamber & $7.34(5.52-9.75)$ & $<0.001$ \\
Non-intact crown & $2.51(1.32-4.76)$ & 0.005 \\
Temporary restoration & $2.14(1.42-3.23)$ & $<0.001$ \\
Resin restoration & $2.09(1.37-3.18)$ & 0.001 \\
\hline
\end{tabular}

may injure pulp tissue (7). In this situation, pulp necrosis often occurs slowly. Pain is more frequent when teeth have periapical lesions. It is important to consider that differences in apical periodontitis image interpretation by using cone beam computed tomography (CBCT) and conventional periapical radiography have been identified (25). CBCT has provided promising results with a more accurate detection of apical periodontitis.

This study found a higher frequency of pulpal and periapical pain in women than in men, and the mean age of the sample was 32 years, in agreement with previous investigations $(5,14,20)$. Chung et al. (20) investigated the prevalence of orofacial pain symptoms in the Korean elderly population, and evaluated factors associated with orofacial pain and graded chronic pain. The results suggested that the 6-month prevalence of joint pain (15.5\%), face pain $(9.3 \%)$, toothache $(26.8 \%)$, oral sores (26.2\%), and burning mouth (14.2\%) in Korean elders were higher than in studies on Caucasian populations. Painful oral sores and burning mouth had higher prevalence for females than for males. Subjects with joint pain, burning mouth or toothache pain were more likely to report high levels of a pain-related disability compared with subjects not reporting those symptoms. There were no age group differences in pain intensity, but the older age group reported a larger number of disability days because of their pain. Lipton et al. (5) evaluated the prevalence and distribution of orofacial pain among adults in the United States and found that toothache was the most frequent symptom, and that women experienced each symptom more often than men with only two exceptions - "toothache and oral sores" and "oral sores and burning mouth".

The prevention of caries and periodontal disease has received special attention in dentistry in the last years, but dental urgencies are often the result of clinical factors such as caries, restorations, coronal fractures, and open pulp chamber. In this study, traumatic dental injuries were included in the "other" category because of the number of cases treated in other University departments. Although, it is essential to mention that a limitation intrinsic in a retrospective study is associate the cause-and-effect relationships. Clinical experience is not sufficient to establish therapeutic guidelines, particularly in the case of odontogenic urgencies. Clinical and biological studies should be conducted to define the best therapeutic protocols. Several parameters should be considered, and it is essential to study endodontic pain, its frequency and clinical factors associated. In this study, 
the highest frequency of odontogenic pain was found in cases of symptomatic pulpitis and symptomatic apical periodontitis of infectious origin. The major clinical factors associated with pains of pulpal and periapical origin were caries and open pulp chamber, respectively.

\section{RESUMO}

Um estudo retrospectivo foi realizado para identificar fatores clínicos e de diagnóstico associado com a dor de origem odontogênica. Foram selecionados 1765 pacientes que buscaram tratamento para dor odontogênica no Serviço de Urgência da Faculdade de Odontologia da Universidade Federal de Goiás. Os critérios de inclusão foram dor de origem pulpar ou periapical antes do tratamento dentário (mínimo de 6 meses depois da última consulta odontológica), e os critérios de exclusão foram dentes com anomalias de desenvolvimento e falta de informações ou registros incompletos. Avaliações clínicas e radiográficas foram realizadas para se obter as características clínicas de dor, incluindo origem, duração, frequência e localização da dor, testes de palpação, percussão e vitalidade pulpar, aspectos radiográficos, diagnóstico endodôntico e características dos dentes. Os testes qui-quadrado e regressão logística múltipla foram utilizados para verificar a associação entre a dor de origem pulpar e periapical e variáveis independentes. O diagnóstico endodôntico de dor de origem pulpar mais frequente foi pulpite sintomática $(28,3 \%)$ seguido por pulpalgia hiper-reativa $(14,4 \%)$, e o mais frequente de dor de origem periapical foi periodontite apical sintomática infecciosa $(26,4 \%)$. Análise de regressão revelou que câmaras pulpares fechadas e cáries estavam altamente associadas à dor pulpar e, inversamente, câmara pulpar aberta estava associada à dor periapical $(\mathrm{p}<0,001)$. $\mathrm{O}$ diagnóstico endodôntico e fatores locais associados com dor de origem pulpar e periapical sugerem que os fatores clínicos importantes das dores pulpares foram câmaras pulpares fechadas e cáries, e de dor periapical foi câmara pulpar aberta.

\section{ACKNOWLEDGEMENTS}

This study was supported in part by grants from the National Council for Scientific and Technological Development (CNPq grants 302875/2008-5 and 474642/2009 to C.E.).

\section{REFERENCES}

1. Seltzer S. Pain. In: Seltzer S (Editor). Endodontology: biologic considerations in endodontic procedures. 2nd ed. Philadelphia: Lea \& Febiger; 1998. p. 471-499.

2. Hargreaves KM. Pain mechanisms of the pulpodentin complex. In: Seltzer and Bender's dental pulp. Hargreaves KM, Goodis HE (Editors).Chicago: Quintessence Publishing; 2002. p. 181-203.

3. Sessle BJ. Recent developments in pain research: central mechanisms of orofacial pain and its control. J Endod 1986;2:435-444.

4. Trowbridge HO. Review of dental pain - histology and physiology. J Endod 1986;12:445-452.

5. Lipton J, Ship JA, Larach-Robinson D. Estimated prevalence and distribution of reported orofacial pain in the United States. J Amer Dent Ass 1993;124:115-121.

6. Smulson MH, Sieraski SM. Histophysiology and diseases of the dental pulps. In: Weine FS. Endodontic therapy. 4th ed. St. Louis: Mosby; 1989. p. 74-153.

7. Estrela $\mathrm{C}$, Holland R. Inflamed dental pulp diagnosis. In: Estrela $\mathrm{C}$ (Editor). Endodontic Science. 2nd ed. São Paulo: Artes Médicas; 2009. p. 155-190.

8. McGrath PA. The measurement of human pulp. Endod Dent Traumatol 1986;2:124-129.

9. Seltzer S, Bender IB, Ziontz M. The dynamics of pulp inflammation: correlation between diagnosis data and actual histologic findings in the pulp. Oral Surg Oral Med Oral Pathol 1963;16:846-871.

10. Langeland K, Blook RM, Grossman LI. A histophatologic and histobacteriologic study of 35 periapical endodontic surgical specimens. J Endod 1977;3:8-23.

11. Abbot PV, Yu C. A clinical classification of the status of the pulp and the root canal system. Aust Dent J 2007;52:17-31(Suppl).

12. Bruno KF, Silva JA, Silva TA, Batista AC, Alencar AHG, Estrela C. Characterization of inflammatory cell infiltrate in human dental pulpitis. Int Endod J 2009;43:1013-1021.

13. Harrison JW, Baumgartner JC, Svec TA. Incidence of pain associated with clinical factors during and after root canal therapy. Part 2. J Endod 1983;9:434-438.

14. Oguntebi BR, DeSchepper EJ, Taylor TS, White CL, Pink FE. Postoperative pain incidence related to the type of emergency treatment of symptomatic pulpitis. Oral Surg Oral Med Oral Pathol 1992;73:479-483.

15. Horiba N, Maekawa Y, Abe Y, Ito M, Matsumoto T, Nakamura H. Correlations between endotoxin and clinical symptoms or radiolucent areas in infected root canals. Oral Surgery Oral Medicine Oral Pathology 1991;71:492-495.

16. Sundqvist G, Eckerbom MI, Larsson AP, Sjögren UT. Capacity of anaerobic bacteria from necrotic dental pulps to induce purulent infections. Infect Immun 1979;25:685-693.

17. Hahn C-L, Liewehr FR. Relationships between caries bacteria, host responses, and clinical signs and symptoms of pulpitis. J Endod 2007;33:213-219.

18. Khabbaz MG, Anastasiadis PL, Sykaras SN. Determination of endotoxins in caries: association with pulpal pain. Int Endod J 2000;33:132-137.

19. Jacinto RC, Gomes BPFA, Shah HN, Ferraz CC, Zaia AA, SouzaFilho FJ. Quantification of endotoxins in necrotic root canals from symptomatic and asymptomatic teeth. J Med Microbiol 2005;54:777-783.

20. Chung JW, Kim JH, Kim HD, Kho HS, Kim YK, Chung SC. Chronic orofacial pain among Korean elders: prevalence, and impact using the graded chronic pain scale. Pain 2004;112:164-170.

21. Eriksen HM, Kirkevang L-L, Petersson K. Endodontic epidemiology and treatment outcome: general considerations. Endod Topics 2002;2:1-9.

22. Estrela C, Holland R, Bernabé PFE, Souza V, Estrela CRA. Antimicrobial potential of medicaments used in healing process in dogs' teeth with apical periodontitis. Braz Dent J 2004;15:181-185.

23. Holland R, Otoboni-Filho JA, Souza V, Mello W, Nery MJ, Bernabé PFE, et al.. Calcium hydroxide and corticosteroidantibiotic association as dressings in cases of biopulpectomy. A comparative study in dogs teeth. Braz Dent J 1998;9:67-76.

24. Varoli FK, Pedrazzi V. Adapted version of the Mcgill pain questionnaire to Brazilian Portuguese. Braz Dent J 2006:17:328-335.

25. Estrela C, Bueno MR, Azevedo B, Azevedo JR, Pecora JD. A new periapical index based on cone beam computed tomography. $\mathrm{J}$ Endod 2008;34:1325-1331.

Received November 28, 2010 Accepted June 20, 2011 